\title{
Strategi Defensif dan Ofensif Parpol Berbasis Massa Islam dalam Mencapai Parliamentary Threshold pada Pemilu 2014
}

\section{Adi Budiman Subiakto}

Yayasan Mata Air, Jakarta

\section{Nur Kafid}

IAIN Surakarta

\begin{abstract}
This study aims to find out political strategy used by the Muslim-based political party to exceed the parliamentary threshold (PT) (3.5\%) on the national election 20I4, with the case study on National Awakening Party (PKB) and National Mandate Party (PAN). Even the survey agency has predicted that those political parties would not be able to reach PT, but the fact showed different. Both of the political parties managed to exceed the specified threshold. Based on the qualitative approach, this study found out that defensive strategy used by PKB, by consolidating and prioritizing the typology of rural voters with ideological approach (nahdliyin), utilizing prominent figures and artist as part of the campaign to achieve success. Meanwhile, by using offensive strategy PAN chose the typology of rural voters, while at the same time also optimizing the typology of urban voters, dialogical and psychological approach, basic societal issues, and the figure of the artist have been successfully gaining the significant voters.
\end{abstract}

\begin{abstract}
Abstrak
Studi ini dilakukan untuk mengungkap strategi politik dari partai politik berbasis massa Islam untuk melampaui angka parliamentary threshold (3.5\%) pada Pemilu tahun 20I4, dengan studi kasus PKB dan PAN. Meski sebelumnya telah diprediksi oleh lembaga survei bahwa mereka tidak akan mampu mencapai angka tersebut, tapi realitas menunjukkan sebaliknya. Kedua Parpol tersebut justru berhasil melampaui ambang batas yang ditentukan. Dengan pendekatan kualitatif, studi ini menemukan bahwa strategi defensif PKB, dengan mengkonsolidasi dan memprioritaskan tipologi pemilih pedesaan, dengan pendekatan ideologis (nahdliyin), menjadikan tokoh dan figur artis sebagai bagian dari kampanye meraih keberhasilan. Sementara PAN, dengan strategi ofensifnya memilih tipologi pemilih pedesaan dengan tetap mengoptimalkan suara dari tipologi pemilih perkotaan, dengan pendekatan dialogis, psikologis, isu kerakyatan, dan figur artis mampu mendulang perolehan suaranya.
\end{abstract}

Keywords: Political-strategy, Parliamentary-threshold, and Islamic political party.

\section{Coressponding author}

Email: adibudimansubiakto@gmail.com mashafid@gmail.com 


\section{Pendahuluan}

Sejarah partai politik Islam di Indonesia tidak bisa dipisahkan dari perkembangan politik umat Islam di Indonesia. Dinamikanya selalu menjadi perhatian para peneliti. Pada jaman Orde Baru, pemerintahan Soeharto menerapkan kebijakan difusi partai politik yang mengakibatkan umat Islam hanya memiliki satu wadah partisipasi politik, yaitu Partai Persatuan Pembangunan (PPP). (Fanani 2013, 73). PPP merupakan difusi dari Partai Nahdlatul Ulama (NU), Partai Sarikat Islam Indonesia (PSII), Partai Muslimin Indonesia (Parmusi), dan Partai Persatuan Tarbiyah Islamiyah (Perti).

Pasca reformasi, seiring dengan terbukanya keran demokrasi, partai politik pun tumbuh subur, termasuk partai-partai politik baru berbasis massa Islam. Politisi dan aktivis Islam memanfaatkan euphoria reformasi dengan mendirikan partai politik. Secara umum, partai Islam sendiri terbagi menjadi dua macam, yaitu partai berasaskan Islam dan partai politik berasaskan Pancasila tapi basisnya massa Islam. Partai politik yang berasaskan Islam seperti Partai Bulan Bintang (PBB), Partai Persatuan Pembangunan (PPP), Partai Keadilan (PK), Partai Majelis Syuro Muslimin Indonesia (Masyumi), dan Partai Umat Islam (PUI). Sementara partai politik yang berasaskan Pancasila namun berbasis massa Islam, seperti Partai Kebangkitan Bangsa (PKB) dan Partai Amanat Nasional (PAN). (Fanani 2013, 76).

Pada Pemilihan Umum (Pemilu) 1999, ada 42 partai politik Islam mendaftarkan diri sebagai peserta Pemilu. Namun hanya 21 partai politik Islam yang lolos verifikasi, dan berhak mengikuti Pemilu tahun 1999. (Fanani 2013, 75). Sisanya, karena belum memenuhi aturan administratif sesuai Undang-Undang (UU) No. 2 tahun 1999 tentang Partai Politik maka tidak bisa ikut kontestasi dalam Pemilu 1999. Meski jumlah Parpol Islam cukup banyak yang ikut serta pada Pemilu 1999, tapi tidak berbanding lurus dengan perolehan kursi di Dewan Perwakilan Rakyat (DPR). Hanya ada 8 Parpol Islam berhasil memperoleh kursi di parlemen. PPP memperoleh 58 kursi, PKB 51 kursi, PAN 34 kursi, PBB 13 kursi, PK 7 kursi, PNU 5 Suara, PSII 1 kursi, dan Partai Politik Islam Indonesia (PPII) Masyumi 1 kursi. (KPU 2009). Realitas ini menunjukkan bahwa keberadaan umat Islam sebagai penduduk mayoritas di Indonesia, tidak serta merta menjadi penentu keberhasilan partai politik berbasis massa Islam.

Berbeda lagi situasinya dengan Pemilu tahun 2004. Melalui UU No. 23 tahun 2003, pemerintah memberlakukan aturan ambang batas perolehan suara parlemen (paliamentary threshold) sebesar 2.5\% suara nasional. Aturan ini dianggap oleh Pamungkas $(2014,34)$ 
sebagai upaya untuk menyederhanakan partai politik dalam suatu sistem multipartai. Situasi ini dianggap oleh para politisi dari Parpol Islam sebagai beban berat. Terbukti, dari 10 Parpol Islam yang menjadi peserta Pemilu hanya 4 Parpol Islam yang berhasil mendudukkan wakilnya di parlemen. Keempat Parpol tersebut adalah PKB, PPP, PKS dan PAN. (Partai Info 2004).

Selanjutnya, Pemilu tahun 2009 tampaknya menjadi momen politik 'menyedihkan' bagi Parpol Islam di Indonesia. Total perolehan suara Parpol Islam pada Pemilu 2009 merupakan hasil terburuk dibanding perolehan suara pada Pemilu tahun 1999 dan 2004. Total perolehan suara Parpol Islam hanya mencapai 29.2\%, dari sebelumnya 41\% suara nasional. (KPU 2009). Padahal parliamentary threshold-nya, berdasar UU No. 10 tahun 2008 masih sama dengan Pemilu sebelumnya, $2.5 \%$ perolehan suara nasional.

Menjelang Pemilu tahun 2014, UU No. 8 Tahun 2012 merubah salah satu pasal mengenai parliamentary threshold yang ditetapkan dalam UU No. 10 tahun 2008, dari 2.5\% naik menjadi 3.5\%. Kondisi ini mendorong Parpol Islam untuk bekerja ekstra keras untuk dapat melampaui angka minimal parliamentary threshold.

Hasil survei Lingkaran Survey Indonesia (LSI) pada tahun 2012 memprediksi bahwa Parpol Islam akan tenggelam dengan perolehan suara kurang dari 5\%. Lain halnya dengan Partai Golongan Karya (Golkar), Partai Demokrasi Indonesia Perjuangan (PDIP), Partai Demokrat (PD), dan Partai Gerakan Indonesia Raya (Gerindra) yang menguasai suara nasional. Secara keseluruhan, perolehan suara Parpol Islam hanya akan mencapai $21.1 \%$. (Viva News 2012). Kemudian pada bulan Maret dan Oktober tahun 2013, LSI kembali melakukan survei Pemilu tahun 2014, dengan hasil yang tidak jauh berbeda. PKB diprediksi akan memperoleh suara nasional 4.5\%, sementara PAN tidak terprediksi. Sedangkan pada survei bulan Oktober tahun 2013, PKB diprediksi memperoleh 4.6\% dan PAN 5.2\% suara nasional. (LSI 2013, 26). Angka ini tergolong mengkhawatirkan, mengingat perolehan suara pada Pemilu tahun-tahun sebelumnya terus merosot.

Namun demikian, hasil survei LSI pada tahun 2012 dan 2013 rupanya meleset dari fakta hasil Pemilu tahun 2014. PKB memperoleh suara yang mengejutkan (9.04\% atau 11.298.957 suara), dan PAN memperoleh suara $7.59 \%$ atau 1.825 .750 suara. Posisi pertama ditempati oleh PDIP (18.95\%), disusul Partai Golkar (14.75\%), Partai Gerindra (11.81\%), dan Partai Demokrat (10.91\%). (Kompas 2014). Artinya, PKB dan PAN berhasil melampaui parliamentary threshold. Dengan kata lain, data ini menunjukkan bahwa Parpol berbasis massa Islam seperti PKB dan PAN masih memiliki daya tarik bagi masyarakat Islam di Indonesia. (PKB 2013).

Berbeda dengan PPP dan PBB yang tidak memiliki 'pangsa pasar' pemilih yang pasti, PKB tampaknya mengandalkan kekuatan suara kalangan Nahdliyin, bahkan mengklaim 
sebagai rumah Nahdliyin. (PKB 2013). (merdeka.com 2014). Sementara PAN, yang awalnya memiliki kedekatan dengan Muhammadiyah tampaknya tidak lagi menjadikan organisasi ini sebagai basis masa utama. PAN dan Muhammadiyah tidak saling mengklaim sebagai satu kesatuan erat, seperti halnya PKB dan NU. (suarapembaruan.com 2013).

PKB dan PAN sepertinya melihat tantangan untuk melabeli diri sebagai Parpol berbasis massa Islam cukup berat. Sementara Parpol nasionalis terus mengakomodir aspirasi umat Islam dengan mendirikan organisasi sayap partai yang bernuansa islami. Ditambah lagi trend islamophobia yang secara tidak langsung juga menjadi bumerang bagi partai-partai dengan basis massa Islam seperti PKB dan PAN. Bagaimanakah strategi politik kedua Parpol tersebut dalam mendulang suara sehingga mampu melampaui parliamentary threshold yang ditetapkan pada Pemilu tahun 2014? Inilah persoalan pokok yang diangkat dalam studi ini.

\section{Strategi Politik}

Strategi dalam pengertian umum diartikan sebagai cara untuk mendapatkan kemenangan atau tercapainya suatu tujuan termasuk politik. Strategi merupakan seni dan ilmu yang menggunakan dan mengembangkan kekuatan-kekuatan secara ideologi, politik, ekonomi, dan lain-lain untuk mencapai tujuan yang telah ditetapkan sebelumnya. (Wuisang n.d.). Strategi lebih dikenal sebagai bagian dari perang dibanding dalam politik. (Pasaribu 2014). Sementara menurut Mahardika (dalam Zainuddin 2014, 15), strategi adalah suatu cara untuk mencapai tujuan. Pencapaian tujuan itu sendiri bergantung pada langkah politik yang dilakukan. Strategi itulah yang pada akhirnya membuat hasil yang berbeda dengan pesaing, sehingga produk yang ditawarkan dapat diingat dalam benak seseorang.

Strategi yang digunakan dalam ranah politik meliputi political branding, ketokohan, isu politik, maupun marketing politik (political marketing). Sebuah strategi yang dilakukan oleh pihak tertentu, tidak menutup kemungkinan untuk ditiru oleh pihak pesaing. Namun political branding, kebijakan, dan isu politik biasanya tidak meniru secara keseluruhan, tapi hanya garis besarnya saja. Mengingat brand yang ditawarkan oleh pihak tertetu akan sangat terkait dengan ciri khas pelaku politik tersebut, yang pasti berbeda dengan pihak lainnya. Pasalnya, branding, kebijakan, dan isu politik itu dilakukan demi mendapatkan posisi politik tertentu di mata pesaing dan konstituen guna mencapai tujuan utama, yakni kemenangan. (Firmanzah 2008, 141).

Namun demikian, untuk menentukan sebuah strategi jitu diperlukan suatu perencanaan strategis, agar hasilnya tepat sasaran atau sesuai dengan tujuan yang diharapkan. Perencanaan strategis itu sendiri terbagi ke dalam dua (2) jenis, yakni strategi offensive (menyerang) dan strategi defensive (bertahan). Strategi offensive dibagi menjadi dua, yaitu strategi memperluas pasar dan strategi menembus pasar. Sementara strategi defensive merupakan strategi untuk 
mempertahankan pasar, menutup, atau menyerahkan pasar. (Schroder 2013, 166).

Strategi ofensif biasanya digunakan jika partai ingin meningkatkan jumlah pemilihnya. Kampanye dapat berhasil jika ada lebih banyak orang yang memiliki pandangan positif terhadap partai dibandingkan sebelumnya. Strategi ofensif yang diterapkan saat kampanye Pemilu menampilkan perbedaan yang jelas dan menarik antara partai tertentu dengan berusaha menarik pendukung partai pesaingnya. Sedangkan strategi defensif jika partai ingin mempertahankan mayoritasnya, atau jika pangsa pasar ingin dipertahankan. (Schroder 2013 , 2). Tapi dalam keadaan tertentu, suatu partai bisa saja menerapkan strategi ofensif dan defensif sekaligus. Meskipun secara strategis keputusan ini selalu berisiko, tapi adakalanya cara ini membawa keberhasilan yang signifikan. Sebuah strategi campuran biasanya terjadi jika salah satu partai dalam koalisi pemerintahan menerapkan strategi defensif terhadap partai oposisi. Pada saat yang sama, di dalam koalisi ia melakukan strategi ofensif terhadap mitra koalisi. (Schroder 2013, 2).

Kampanye sebagai salah satu tahapan dari pelaksanaan Pemilu, merupakan masa di mana strategi politik yang sudah dirancang dituntut untuk bisa diaplikasikan, guna mendulang perolehan suara bagi seorang calon atau partai politik. Masa kampanye merupakan masa bagi seorang calon atau partai politik untuk berkomunikasi dan meyakinkan para konstituen agar mau memilihnya. Oleh sebab itu, kegiatan kampanye bisa dikatakan sebagai aktifitas atau usaha untuk mempengaruhi rakyat secara persuasif dengan menggunakan retorika, hubungan (kedekatan) dengan rakyat, komunikasi massa, dan lobi. Aktor politik (calon) dan partai politik sebagai komunikator politiknya. (Arifin 2003, 134).

Agar proses komunikasi politik dapat berjalan lancar, dan pesan yang diharapkan tersampaikan secara tepat, diperlukanlah marketing politik. Istilah ini, pada awalnya merupakan konsep yang digunakan oleh para pelaku ekonomi, yang menekankan prinsip dasar melakukan pengeluaran seminimal mungkin, tapi mendapatkan penghasilan semaksimal mungkin. (Firmanzah 2008, 128). Tapi dalam konteks politik, konsep ini menjadi bagian dari strategi politik untuk mendekati konstituen secara proporsional. Efektif dan efisien menjadi prinsip yang harus dipegang oleh bagian marketing politik. Bukan hanya platform yang coba dipublikasikan, tapi juga ideologi, isu, gagasan, serta track record dari para kontestan. (Firmanzah 2008, 156).

\section{Parliamentary Threshold}

Parliamentary Threshold (PT) adalah ambang batas perolehan suara yang harus dicapai oleh partai politik untuk dapat mengirimkan calon terpilihnya ke lembaga perwakilan (parlemen). Partai politik yang perolehan suaranya sama dengan atau melampaui PT akan diikutsertakan dalam perhitungan perolehan kursi Dewan Perwakilan Rakyat (DPR) 
merujuk pasal 208 Undang-Undang (UU) No. 8 tahun 2012. Sementara ketentuan PT tidak berlaku untuk perhitungan kursi Dewan Perwakilan Rakyat Daerah (DPRD) Provinsi dan DPRD Kabupaten/Kota, yang dihasilkan melalui keputusan Mahkamah Konstitusi No. 52/ PUU-X/2012. (Perdana 2013).

Aturan tersebut baru digunakan di Indonesia pada tahun 2004, dengan diberlakukannya UU No. 23 tahun 2003, dengan besaran angka 2.5\%. Angka yang sama juga berlaku pada Pemilu 2009 berdasarkan UU No. 10 tahun 2008. Kemudian besaran angka ambang batas naik prosentasenya menjadi 3.5\% setelah diberlakukan UU No. 8 tahun $2012 .{ }^{1}$

Pemberlakukan aturan ini pada awalnya tidak serta merta berjalan mulus. Muncul berbagai kontroversi atas pemberlakukan aturan ini. Ada pihak yang menyatakan bahwa aturan ini sebagai bentuk campur tangan pemerintah dalam proses penyederhanaan partai politik dalam sistem multipartai (Pamungkas 2014, 34). Ada pula yang menyatakan sebagai kebijakan efektif dalam membatasi jumlah partai politik di parlemen (Denysa 2009, 43). Pasalnya, dengan aturan ini akan mampu mendorong partai politik untuk lebih serius berkerja dalam meraih dukungan dan menjaga legitimasi yang diberikan oleh rakyat sebagai konstituennya. (Prihatmoko 2008, 148). Kontroversi pun berlanjut sampai pada pengajuan judicial review atas UU Pemilu ke Mahkamah Konstitusi (MK). Hingga keluarlah putusan MK Nomor 52/PUU-X/2012 yang menyatakan bahwa angka 3.5\% untuk Parliamentary Threshold dalam Pasal 208 UU No. 8 tahun 2012, selain frase "DPRD Provinsi, dan DPRD Kabupaten/ Kota" sama sekali tidak bertentangan dengan Undang-Undang Dasar (UUD) 1945. Kebijakan tersebut berdasar pada perhitungan objektif partai peserta Pemilu sebelumnya dengan keseluruhan anggota parlemen/DPR. (Perdana 2013, 68).

Kebijakan PT berbeda dengan Electoral Threshold (ET). ET merupakan ambang batas perolehan suara partai politik untuk bisa ikut serta sebagai kontestan Pemilu. Jika partai politik tertentu tidak dapat memenuhi angka ET yang telah ditetapkan, maka partai politik tersebut secara langsung tidak dapat mengikuti Pemilu berikutnya. (Denysa 2009, 5455). Sebagai contoh Partai Damai Sejahtera (PDS), Partai Demokrasi Kebangsaan (PDK), Partai Karya Peduli Bangsa (PKPB) dan Partai Pelopor. (Denysa 2009, 57). Sementara PT lebih kepada jumlah dukungan suara dalam batasan tertentu untuk diikutsertakan dalam perhitungan suara partai politik di parlemen.

\section{Strategi Defensive PKB dan Offensive PAN}

Pada saat Pemilu tahun 2009, perolehan suara nasional partai politik berbasis massa Islam tidaklah baik. Padahal di Pemilu 2004, mereka memperoleh cukup banyak kursi di DPR.

1 Bunyi Undang-Undang Nomor 8 Tahun 2012 Pasal 208 ayat 1 (satu) tentang Pemilihan Umum adalah : 'Partai politik peserta Pemilihan Umum harus memenuhi ambang batas perolehan suara sekurang-kurangnya 3.5\% dari jumlah suara sah secara nasional untuk diikutkan dalam penentuan perolehan kursi anggota DPR, DPRD Provinsi, dan DPRD Kabupaten/Kota”. 
PKB hanya memperoleh 4.94\% pada Pemilu tahun 2009, padahal di tahun 2004 memperoleh posisi ketiga dengan perolehan suara $10.57 \%$. PAN pun bernasib sama, meskipun penurunan suaranya tidak terlalu signifikan seperti PKB. PAN memperoleh suara $6.44 \%$ pada Pemilu tahun 2004, dan menurun menjadi 6.04\% pada Pemilu 2009.

Kenaikan PT menjadi 3.5\% merupakan tantangan berat bagi partai politik berbasis Islam pada Pemilu 2014. Pada Pemilu tahun 2009 saja, angka 2.5\% sudah cukup merepotkan partai politik berbasis Islam dalam mengelola dan menyusun strategi. Namun demikian, partai politik berbasis massa Islam, seperti PKB dan PAN masih optimis dengan aturan kenaikan PT menjadi 3.5\%. Angka ini dianggap cukup moderat bagi partai politik yang dikategorikan sebagai partai politik kelas menengah ini. Alasanya, jika PT dinaikkan menjadi 4\% atau 5\%, diyakini akan mengeliminasi eksistensi partai politik kelas menengah ini.

Ada beberapa aspek menarik dari partai politik dalam proses kampanye pada masa Pemilu tahun 2014, seperti pencitraan, tema pesan kampanye, figur atau tokoh, simbolsimbol yang dimunculkan, dan jargon (tagline) politik dari masing-masing partai politik. Aspek-aspek itulah yang dijadikan sebagai political branding bagi PKB dan PAN untuk mencapai angka ambang batas. Namun demikian, ada perbedaan menarik untuk dicermati dari implementasi strategi kedua partai ini. Perbedaan itulah yang kemudian berdampak pada upaya political branding yang dilakukan kedua partai tersebut.

PKB memilih untuk menggunakan strategi defensif, dengan cara mempertahankan segmentasi pemilih yang berasal dari kalangan Nahdliyin. Selain itu, PKB juga berkaca pada Pemilu tahun 2009 di mana gejolak internal partai berimbas pada penurunan perolehan suaranya. Sehingga langkah awal yang ditempuh oleh Muhaimin Iskandar sebagai Ketua Umum adalah dengan melakukan pembenahan internal partai. Selanjutnya, dengan melihat NU sebagai benteng utamanya, PKB pun kembali merapatkan barisan keluarga besar NU yang selama ini terpecah. Citra sebagai partai milik warga NU pun kembali didengungkan.

Muhaimin Iskandar menganalogikan PKB sebagai sebuah pohon, yang akarnya menancap ke bawah bersama NU, sedangkan dahannya menjulang ke atas bersama tokohtokoh yang mumpuni di bidangnya masing-masing, sementara buahnya dapat dirasakan oleh seluruh masyarakat Indonesia, terlebih warga Nahdliyin. Dari sinilah PKB kemudian menggunakan pendekatan ideologi Aswaja yang selama ini menjadi ideologi NU. Tagline "Politik rahmatan lil 'alamin" pun diusung oleh PKB demi mempertahankan basis suara warga NU. (Wawancara SM 24 Februari 2015). Sebagai implementasi dari tagline itu, PKB pun getol menyelenggarakan kegiatan-kegiatan keagamaan khas NU, seperti tahlilan, Isra Mi'raj, dan tradisi lainnya. Karena basis massa NU mayoritas berada di wilayah pedesaan, maka sasaran kegiatan tersebut pun dilakukan di lokasi yang menjadi kantong-kantong warga NU. Termasuk mendekati tokoh-tokoh di daerah pedesaan, terutama para 'Kyai Kampung' yang 
selama ini memang menjadi salah satu motor penggerak utama kehidupan di lingkungan pedesaan. Meski mereka adalah tokoh agama, tetapi keberadaan mereka selama ini cukup signifikan untuk menjadi rujukan warga, termasuk dalam hal menentukan pilihan politik. Sebagaimana terlihat jelas pada masa pemilihan presiden (Pilpres) 2014, di mana para capres saling berkompetisi dalam mendekati para Kyai Kampung untuk menaikkan polpularitas dan elektabilitas mereka, maupun dalam dalam menepis berbagai bentuk kampanye hitam (black campign).(Kafid 2014, 342-343).

Strategi lain yang diterapkan oleh $\mathrm{PKB}$ adalah political branding ketokohan. PKB menjadikan para tokoh nasional, tokoh NU, dan artis sebagai juru kampanyenya. Beberapa diantaranya adalah M. Mahfudz MD, Jusuf Kalla, Rhoma Irama, K.H. Hasyim Muzadi, K.H. Said Aqil Siraj, Ahmad Dhani, Khofifah Indarparawangsa. Bahkan, Gus Dur pun masih dijadikan sebagai icon utamanya. Pasalnya, selain sebagai pendiri, sosok Gus Dur memang tidak bisa dilepaskan dari PKB. (Wawancara HF 5 Maret 2015). Tampilnya para tokoh NU dalam masa kampanye ini, menjadi citra keberhasilan PKB dalam menyatukan kembali keluarga besar NU, sehingga turut memberikan pengaruh besar dalam perolehan suara $\mathrm{PKB}$ pada Pemilu tahun 2014.

Strategi berikutnya, PKB pun melakukan konvensi terbuka untuk calon Presiden yang akan diusung pada Pemilu tahun 2014. Proses konvensi pada akhirnya memunculkan tiga tokoh nasional, yakni Jusuf Kalla, Rhoma Irama, dan M. Mahfud MD. Dari konvensi ini PKB menekankan kepada para Bakal Capres-nya untuk berkampanye di wilayah basis massanya masing-masing. Rhoma Irama dengan basis penggemar atau fans di wilayah pedesaan, $\mathrm{M}$. Mahfud MD di lingkungan kampus, dan M. Jusuf Kalla untuk menggarap wilayah Timur Indonesia. Wilayah di mana PKB sendiri masih tergolong minim konstituen.

Keterlibatan figur artis seperti Rhoma Irama mempunyai pengaruh signifikan karena adanya basis massa atau fans tersendiri. Rhoma bahkan berhasil menjadi vote getter, yang dianggap menjadi salah satu faktor naiknya suara PKB. Fans Rhoma Irama yang mayoritas berasal dari kalangan petani dan masyarakat pedesaan, merupakan salah satu alasan mengapa PKB memprioritaskan daerah pedesaan sebagai tipologi utama pemilih menjadi sesuai.

Selain itu, menghadapi ketatnya kompetisi partai politik, PKB sadar bahwa pembangunan citra positif sangat diperlukan untuk membentuk persepsi masyarakat. Pada Pemilu tahun 2014, PKB berhasil membentuk sebuah citra sebagai partai anak muda. PKB menampilkan para Calon Legislatif (Caleg)-nya dari kalangan artis muda, seperti Tommy Kurniawan, Krisna Mukti, Ressa Herlambang, dan Ridho Rhoma. Karena selama ini mereka sudah menjadi public fugure maka secara tidak langsung media, baik cetak maupun elektronik, pun terus mengikuti perkembangan yang terjadi di PKB. Bahkan dalam iklan politiknya, PKB pun menampilkan sosok musisi yang digandrungi anak-anak muda, seperti Ahmad Dhani 
dan anaknya Al-Ghazali (Al) sebagai Juru Kampanye. Hal ini menjadi daya tarik tersendiri bagi anak-anak muda, terutama para pemilih pemula. Sebagaimana dikatakan Ketua DPP PKB, Marwan Ja'far, karena Al sedang 'naik daun' atau digandrungi oleh anak-anak muda, maka ia dipasang agar pemilih pemula mau memilih PKB. (Tempo.co 2014).

Dari sini terlihat jelas bahwa pemetaan yang dilakukan partai politik, terutama PKB itu didasarkan atas segmentasi pemilih. Karena pada dasarnya masyarakat itu memang terbagi ke dalam beberapa lapisan atau segmen, maka partai politik pun turut memetakan lapisan dan segmentasi masyarakat guna membedakan kemasan dan pesan politik di setiap lapisan dan segmennya. Penempatan Caleg maupun Juru Kampanye pun dilakukan berdasarkan segmentasi tersebut. Tujuannya tiada lain adalah agar strategi yang digunakan bisa tepat sasaran, yaitu masyarakat mendukung dan memberikan suaranya. Namun demikian, fokus garapan PKB masih berkutat di Pulau Jawa. PKB belum mampu menarik pangsa pasar di luar Pulau Jawa secara signifikan. Terlihat dari 46 anggota DPR RI yang terpilih dari PKB, 33 kursi berasal dari daerah pemilihan di Pulau Jawa, dan hanya 13 orang dari luar Pulau Jawa.

Secara garis besar, naiknya perolehan suara PKB secara signifikan pada Pemilu tahun 2014 dikarenakan dua faktor: pertama, kembalinya suara warga NU ke PKB, dan kedua, pengaruh keterlibatan para artis, terutama Rhoma Irama. Sebagaimana diakui oleh Helmi Faisal, Pengurus DPP PKB, bahwa pengaruh Rhoma Irama itu terlihat di daerah Aceh, Jawa Barat, dan Nusa Tenggara barat (NTB). Sementara pengaruh kembalinya NU terlihat di Pulau Jawa. (Viva.co.id n.d.).

Sedangkan PAN, secara umum menggunakan strategi ofensif. Sejak Pemilu tahun 2009, PAN masuk pada pemilih dengan tipologi pedesaan. PAN yang awalnya sebagai partai Muhamadiyah, partai (berbasis) kampus, dan partai (berbasis) perkotaan mencoba bertransformasi menjadi partai religi-kerakyatan. PAN mulai sedikit menyingkirkan label Muhammadiyah yang melekat, dan berharap menjadi partai semua golongan. (Wawancara YS 20 April 2015).

PAN menerapkan strategi terjun langsung ke masyarakat langsung. Para Caleg dan kader PAN didorong untuk berkomunikasi langsung, mendengarkan keluhan, menyampaikan program, dan melaksanakan program sebagai titik tekan strateginya. Sebagaimana ditegaskan Zulkifli Hasan, Ketua Umum PAN, bahwa ada sanksi tegas berupa penggantian jika anggota legislatif dari PAN tidak turun langsung ke masyarakat. (Viva.co.id n.d.). PAN menganggap hubungan kedekatan dengan masyarakat dibangun guna menjaga konstituen agar tidak lari ke partai lain.

Selain itu, guna menaikkan perolehan suara PAN menjalankan aturan ketat bagi para Caleg untuk turun ke daerah pemilihannya (Dapil) masing-masing. Bahkan bagi para anggota DPR dari PAN diwajibkan untuk melakukan pendekatan saat reses guna mempertahankan 
suara partai, maupun anggota itu sendiri untuk Pemilu yang akan datang. Ini merupakan strategi alternatif yang dilakukan oleh PAN karena tidak adanya tokoh sentral (central figure) yang kuat.

Dalam memilih segmentasi pemilih pun, PAN tidak lagi menjadikan Muhammadiyah sebagai fokus utama strateginya. PAN menyadari bahwa mayoritas warga Muhammadiyah yang rata-rata berpendidikan dan tinggal di wilayah perkotaan, sudah banyak yang beralih ke partai lain. PAN merasa harus melakukan penetrasi ke wilayah pedesaan, tapi dengan tanpa mengesampingkan strategi defensif guna mempertahankan basis massanya di wilayah perkotaan. Terbukti di beberapa daerah yang mayoritas penduduknya NU, PAN berhasil mengusung Caleg-nya. Yandri Susanto, berhasil menggarap suara pemilih NU di Dapil Banten I untuk beralih ke PAN. Strategi ini termasuk cukup berhasil. Jika dibandingkan dengan PKB, PAN memiliki jumlah kursi di DPR lebih banyak, meski perolehan suaranya berada di bawah PKB. Namun sebaran perolehan suara PAN di luar Jawa lebih banyak (sebanding dengan 24 kursi) dibanding PKB yang hanya 13 kursi. Meskipun untuk sebaran suara di Pulau Jawa, PAN hanya mendapatkan 25 kursi, jauh di bawah PKB (33 kursi).

Untuk konteks political branding, strategi yang dilakukan PAN pada Pemilu tahun 2014 hampir sama dengan PKB, yakni dengan melibatkan figur artis sebagai calon legislatifnya. Namun strategi ini dilengkapi oleh PAN dengan pelaksanaan program sosial, seperti bansos dan pendekatan door to door dari para Calegnya. (Wawancara VYM 11 Mei 2015).

Jika dilakukan perbandingan, strategi politik yang dilakukan oleh PKB maupun PAN maka akan terlihat kesamaan. Kedua partai politik ini menjadikan artis sebagai calon anggota legislatif (Caleg) sebagai bagian dari strategi politik untuk mengdongrak perolehan suara partainya. Realitasnya, banyak Caleg dari kalangan artis yang berhasil melenggang ke Senayan berasal dari kedua partai berbasis massa Islam ini. Selanjutnya, baik PKB maupun PAN masih memandang ketokohan atau figur sebagai vote getter dalam menentukan pilihan politik.

\section{Kesimpulan}

Partai politik berbasis massa Islam, khususnya PKB dan PAN memandang parliamentary threshold sebagai sebuah kebijakan yang baik untuk menyaring partai-partai politik di sebuah sistem Pemilu dengan multipartai. Kenaikan angka PT, dari 2.5\% menjadi 3.5\% menjadi tantangan tersendiri bagi partai-partai kelas menengah untuk lebih serius bekerja keras dan memelihara kepercayaan dari para pemilihnya agar tetap bisa ikut serta dalam kontestasi pada Pemilu berikutnya. Realitasnya, ada lembaga survei yang memprediksi bahwa partaipartai Islam dan berbasis massa Islam tidak akan lolos PT, justru terbantahkan dengan keberhasilan dua partai ini. 
Dengan strategi defensifnya, mempertahankan basis massa di wilayah pedesaan, $\mathrm{PKB}$ berhasil melampaui PT 3.5\% suara nasional. Tetapi, strategi ini dilengkapi oleh PKB dengan menerapkan konvensi terbuka untuk Calon Presiden yang akan diusung, menghadirkan tokoh-tokoh ulama penting dari kalangan nahdliyin sebagai simbol penyatuan suara keluarga besar NU, serta melibatkan Caleg dan Juru Kampanye dari kalangan artis. Walaupun beberapa caleg artis gagal melenggang ke Senayan, tapi mereka tetap memberikan kontribusi suara untuk PKB.

Sedangkan PAN dalam melampaui PT 3.5\% suara nasional dengan menerapkan strategi ofensif, meski tidak mengesampingkan strategi defensif. Hal ini terlihat dari pergeseran segmentasi pemilih. PAN yang dalam beberapa Pemilu sebelum tahun 2014 dikenal sebagai partai perkotaan, pada Pemilu tahun 2014 melakukan penetrasi ke wilayah pedesaan. Di sini, PAN mewajibkan setiap Caleg-nya untuk turun langsung ke jantung suara, karena kesadaran atas tidak adanya figur sentral. Dengan strategi ini, PAN berhasil mensinergiskan antara tagline "Politik Merakyat" dengan kinerja yang dilakukan oleh para calegnya, sehingga berhasil membangun citra politik sebagai partai politik yang mengedepankan isu-isu kerakyatan. Selain itu, PAN juga berhasil menggunakan Caleg dari kalangan artis sebagai strategi vote getter-nya. Hal ini bisa dilihat dari beberapa anggota DPR dari PAN yang dari kalangan artis, seperti Anang Hermansyah dan Desy Ratnasari.

\section{Referensi}

Arifin, Anwar. 2003. Komunikasi Politik: Paradigma, Teori, Aplikasi, Strategi dan Komunikasi Politik Indonesia. Jakarta: Balai Pustaka.

Denysa, Haldyan. 2009. Implementasi Perbandingan Electoral Threshold dalam Pemilu 2004 dan Pemilu 2009. Yogyakarta: Fakultas Hukum, UII.

Fanani, Ahmad Fuad. 2013. “Dilema Partai Politik berbasis Islam: Terpuruk dalam Kegagalan atau Menjawab Tantangan?'”' Jurnal Maarif: 73.

Firmanzah. 2008. Marketing Politik. Jakarta: Yayasan Obor Indonesia.

Kafid, Nur. 2014. "From Personal to Social Transformation: A Phenomenological Study on the Life of 'Kyai Kampung."' Komunitas: International Journal of Indonesian Society and Culture 6 (3): 336-44. doi:10.15294/komunitas.v6i1.3313.

Kompas. kompas.com. Mei 9, 2014. http://nasional.kompas.com/read/2014/05/09/2357075/ Disahkan.KPU.Ini.Perolehan.Suara.Pemilu.Legislatif.2014 (accessed Juni 19, 2014).

KPU. kpu.go.id. Februari 21, 2009. http://.kpu.go.id/index.php/pages/detail/2008/11/ Pemilu-1999 (accessed April 15, 2015).

—.kpu.go.id. 2009. http://kpu.go.id/dmdocuments/modul_1d.pdf (accessed April 15, 2015). LSI. 2013. Index Capres Pemilu 2014: Capres Riil versus Capres Wacana. Jakarta: LSI.

Merdeka.com. merdeka.com. Agustus 29, 2014. http://www.merdeka.com/politik/ kemenangan-pkb-di-Pemilu-2014-karena-keramat-kiai-sepuh.html (accessed April 
15, 2015).

Partai Info. Partai Info. Mei 5, 2004. http://partai.info/Pemilu2004/hasilPemilulegislatif.php (accessed Juni 18, 2014).

Pasaribu, Rowland B.F. "gunadarma.ac.id.” gunadarma.ac.id. 2014. http://rowland_pasaribu. staff.gunadarma.ac.id/download/files/bab-09-politik-dan-strategi-nasional.pdf (accessed Juni 16, 2015).

Perdana, Aditya dkk. 2013. Panduan Calon Legislatif Perempuan untuk Pemilu 2014. Depok: Puskapol UI.

PKB. dpp.pkb.or.id. Januari 13, 2013. http://dpp.pkb.or.id/harmoni-nu-pkb-muluskankemenangan-di-Pemilu-2014 (accessed April 15, 2015).

-. dpp.pkb.or.id. Januari 13, 2013. http://dpp.pkb.or.id/harmoni-nu-pkb-muluskankemenangan-di-Pemilu-2014 (accessed April 15, 2015).

Prihatmoko, Joko J. 2008. Mendemokratiskan Pemilu dari Sistem sampai Elemen Teknis. Yogyakarta: Pustaka Pelajar.

Schroder, Peter. 2013. Strategi Politik. Jakarta: Freiderich-Naumann-Stiftung fur die Freiheit.

Suarapembaruan.com. suarapembaruan.com. Januari 24, 2013. http://www.suarapembaruan. com/ home/muhammadiyah-tak-lagi-merasa-bagian-pan/29562 (accessed April 15, 2015).

Tempo.co. tempo.co. Maret 9, 2014. http://www.tempo.co/read/news/2014/03/09/270560673/ Al-Ahmad-Dhani-Jadi-Juru-Kampanye-PKB (accessed April 24, 2015).

Viva News. m.news.viva.co.id. Oktober 14, 2012. http://m.news.viva.co.id/news/read/359256survei--partai-islam-jeblok-demokrat-rontok-2014 (accessed Juni 19, 2014).

Viva.co.id. Viva.co.id. n.d. http://politik.news.viva.co.id/news/read/496237pkb--rhoma-effect-terlihat-di-aceh--jawa-barat--dan-ntb?fb_comment_ $\mathrm{id}=445755115569730 \_2304820 \#$ f25b455a64 (accessed Mei 11, 2015).

- $\quad$ Viva.co.id. n.d. http://politik.news.viva.co.id/news/read/496237-pkb-rhoma-effect-terlihat-di-aceh--jawa-barat--dan-ntb?fb_comment_ id=445755115569730_2304820\#f25b455a64 (accessed Mei 2015, 2015).

-. Viva.co.id. n.d. http://politik.news.viva.co.id/news/read/496237-pkb-rhoma-effect-terlihat-di-aceh--jawa-barat--dan-ntb?fb_comment_ id=445755115569730_2304820\#f25b455a64 (accessed Mei 11, 2015).

Zainuddin. 2014. Strategi Partai Amanat Nasional (PAN) dalam memenuhi kuota 30 persen keterwakilan perempuan dalam daftar calon legislatif pada Pemilihan Umum tahun 2014 di Kota Samarinda. Samarinda: FISIP, Universitas Mulawarman.

Wuisang, Audy W.M.R. poltramas.com. n.d. http://www.poltramas.com (accessed Agustus 20, 2014). 